\title{
Tumor-suppressive microRNA-29 family inhibits cancer cell migration and invasion directly targeting $L O X L 2$ in lung squamous cell carcinoma
}

\author{
KEIKO MIZUNO $^{1}$, NAOHIKO SEKI ${ }^{2}$, HIROKO MATAKI ${ }^{1}$, RYOSUKE MATSUSHITA ${ }^{3}$, KAZUTO KAMIKAWAJI ${ }^{1}$, \\ TOMOHIRO KUMAMOTO ${ }^{1}$, KOICHI TAKAGI ${ }^{1}$, YUSUKE GOTO $^{2}$, RIKA NISHIKAWA ${ }^{2}$, MAYUKO KATO ${ }^{2}$, \\ HIDEKI ENOKIDA ${ }^{3}$, MASAYUKI NAKAGAWA ${ }^{3}$ and HIROMASA INOUE ${ }^{1}$
}

\author{
${ }^{1}$ Department of Pulmonary Medicine, Graduate School of Medical and Dental Sciences, Kagoshima University, \\ Kagoshima 890-8520; ${ }^{2}$ Department of Functional Genomics, Chiba University Graduate School of Medicine, Chiba 260-8670; \\ ${ }^{3}$ Department of Urology, Graduate School of Medical and Dental Sciences, Kagoshima University, Kagoshima 890-8520, Japan
}

Received September 28, 2015; Accepted October 26, 2015

DOI: 10.3892/ijo.2015.3289

\begin{abstract}
Lung cancer remains the most frequent cause of cancer-related death in developed countries. A recent molecular-targeted strategy has contributed to improvement of the remarkable effect of adenocarcinoma of the lung. However, such treatment has not been developed for squamous cell carcinoma (SCC) of the disease. Our recent studies of microRNA (miRNA) expression signatures of human cancers showed that the microRNA-29 family (miR-29a, miR-29b and $m i R-29 c$ ) significantly reduced cancer tissues compared to normal tissues. These findings suggest that $m i R-29 s$ act as tumor-suppressors by targeting several oncogenic genes. The aim of the study was to investigate the functional significance of $m i R-29 s$ in lung SCC and to identify $m i R-29 s$ modulating molecular targets in lung SCC cells. Restoration of all mature members of the miR-29s inhibited cancer cell migration and invasion. Gene expression data combined in silico analysis and luciferase reporter assays demonstrated that the lysyl oxidase-like 2 (LOXL2) gene was a direct regulator of tumor-suppressive $m i R-29 s$. Moreover, overexpressed LOXL2 was confirmed in lung SCC clinical specimens, and silencing of $L O X L 2$ inhibited cancer cell migration and invasion in lung SCC cell lines. Our present data suggested that loss of tumor-suppressive $m i R-29 s$ enhanced cancer cell invasion in lung SCC through direct regulation of oncogenic LOXL2. Elucidation of the novel lung SCC molecular pathways and targets regulated by tumor-suppressive $m i R-29 s$ will provide
\end{abstract}

Correspondence to: Professor Hiromasa Inoue, Department of Pulmonary Medicine, Graduate School of Medical and Dental Sciences, Kagoshima University, 8-35-1 Sakuragaoka, Kagoshima 890-8520, Japan

E-mail: inoue-pulm@umin.net

Key words: lung squamous cell carcinoma, microRNA, $m i R-29 a$, $m i R-29 b, m i R-29 c$, lysyl oxidase-like 2 new insights into the potential mechanisms of oncogenesis and metastasis of the disease.

\section{Introduction}

Lung cancer remains the most frequent cause of cancer-related death in developed countries, and an estimated 1.8 million new cases of lung cancer occurred in 2012 (1). Approximately 80\% of lung cancers are classified histopathologically as non-small cell lung cancer (NSCLC), and NSCLC are subdivided into four major histological subtypes: adenocarcinoma, squamous cell carcinoma (SCC), large cell carcinoma, and neuroendocrine cancer (2). NSCLC, as compared to small cell lung cancer, is less sensitive to anticancer drugs and radiation therapy. Recently, molecular target therapies for adenocarcinoma (gefitinib, erlotinib and crizotinib) have shown remarkable therapeutic efficacy; however, no targeted therapeutics are currently approved for treatment of lung SCC (3). Therefore, the lung squamous cell carcinomas need a new treatment option.

The human genome sequence era and the discovery of microRNAs (miRNAs) in human genomes have brought great changes to the study of human cancers. miRNAs are endogenous small non-coding RNA molecules (19-22 bases in length) that regulate protein-coding gene expression by repressing translation or cleaving RNA transcripts in a sequence-specific manner $(4,5)$. Substantial evidence suggests that miRNAs are aberrantly expressed in many human cancers and play significant roles in human oncogenesis and metastasis $(6,7)$. The nature of miRNAs is unique in that one miRNA has the ability to regulate multiple protein-coding RNAs. Bioinformatic predictions indicate that miRNAs regulate $30-60 \%$ of the protein-coding genes in the human genome $(5,6)$. Therefore, identification of tumor-suppressive or oncogenic miRNAs and the miRNAs-mediated novel cancer networks are the first step toward elucidating the molecular mechanisms of human cancers.

Based on this foregoing discussion, we sequentially identified tumor-suppressive miRNAs and the miRNA-regulated oncogenic genes in various types of cancers (8-11). A recent 
study of lung SCC showed that miRNA-1/133a-clustered miRNAs inhibit cancer cell migration and invasion by targeting the CORO1C gene encoding a member of the WD repeat protein family and is involved in a variety of cellular processes (12). Moreover, tumor-suppressive $m i R$-206 inhibited dual signaling networks activated by MET and EGFR in lung SCC cells (13).

Our miRNA expression signatures of human cancers demonstrated that the miR-29 family $(m i R-29 a, m i R-29 b$, and $m i R-29 c)$ was downregulated in cancer tissues compared to normal tissues $(8,9,14-17)$, suggesting that these miRNAs function as tumor suppressors in lung SCC cells. However, $m i R-29 s$-regulating molecular networks have not been sufficiently analyzed in this disease. The aim of this study is to investigate the functional significance of $m i R-29 s$ in lung SCC and to identify $m i R-29 s$-regulating molecular targets in lung SCC cells.

In this study, we found that the restoration of all $m i R-29 s$ inhibited cancer cell migration and invasion, directly targeting the lysyl oxidase-like 2 (LOXL2) gene. Moreover, overexpression of LOXL2 was detected in lung SCC clinical specimens, and silencing of LOXL2 significantly inhibited cell migration and invasion by cancer cells. The tumor-suppressive miR-29-LOXL2 axis may provide new insights into the potential mechanisms of lung SCC oncogenesis and metastasis.

\section{Materials and methods}

Clinical specimens and RNA extraction. A total of 32 lung SCCs and 22 normal lung specimens were collected from patients who underwent pneumonectomy at Kagoshima University Hospital from 2010 to 2013. The patient backgrounds and clinical characteristics are summarized in Table I. Archival formalin-fixed paraffin-embedded (FFPE) samples were used for qRT-PCR analysis and immunohistochemistry.

Samples were staged according to the International Association for the Study of Lung Cancer TNM classification, and they were histologically graded (18). This study was approved by the Institutional Review Board for Clinical Research of Kagoshima University School of Medicine. Prior written informed consent and approval were provided by each patient.

FFPE tissues were sectioned to a thickness of $10 \mu \mathrm{m}$, and 8 tissue sections were used for RNA extraction. Total RNA (including miRNA) was extracted using Recover All ${ }^{\mathrm{TM}}$ Total Nucleic Acid Isolation kit (Ambion, Austin, TX, USA) using the manufacturer's protocol. The integrity of the RNA was checked with an RNA 6000 Nano assay kit and a 2100 Bioanalyzer (Agilent Technologies, Santa Clara, CA, USA).

Cell culture and RNA extraction. We used human lung SCC cell lines (EBC-1 and SK-MES-1) obtained from the Japanese Cancer Research Resources Bank (JCRB) and the American Type Culture Collection (Manassas, VA, USA), respectively. Cells were grown in RPMI-1640 medium supplemented with $10 \%$ fetal bovine serum (FBS) and maintained in a humidified incubator $\left(5 \% \mathrm{CO}_{2}\right)$ at $37^{\circ} \mathrm{C}$.

Total RNA was isolated using Isogen (Nippon Gene, Tokyo, Japan) according to the manufacturer's protocol. The integrity of the RNA was checked with an RNA 6000 Nano assay kit and a 2100 Bioanalyzer (Agilent Technologies).

Quantitative reverse transcription PCR ( $q R T-P C R)$. The procedure for PCR quantification was described previously (9-11). TaqMan probes and primers for LOXL2 (P/N: Hs00158757_m1; Applied Biosystems, Foster City, CA, USA) were assay-on-demand gene expression products. Stem-loop RT-PCRs for $m i R-29 a(\mathrm{P} / \mathrm{N}: 002112$; Applied Biosystems), $m i R-29 b(\mathrm{P} / \mathrm{N}: 000413)$, and $m i R-29 c(\mathrm{P} / \mathrm{N}: 000587)$ were used to quantify the expression levels of miRNAs according to the manufacturer's protocol. To normalize the data for quantification of mRNA and miRNAs, we used human GUSB (P/N: Hs99999908_m1; Applied Biosystems) and RNU48 (P/N: 001006; Applied Biosystems), respectively.

Transfections with mature miRNA and small interfering RNA (siRNA) into cell lines. The following mature miRNA species were used in the present study: Pre-miR ${ }^{\mathrm{TM}}$ miRNA precursors (hsa-miR-29a-3p, P/N: AM 12499; hsa-miR-29b-3p, P/N: AM 10103; hsa-miR-29c-3p, P/N: AM 10518; and negative control miRNA, P/N: AM 17111), Stealth Select RNAi siRNA, si-LOXL2 (P/N: HSS106124, P/N: HSS106125 and P/N: HSS180848; Invitrogen, Carlsbad, CA, USA), and negative-control siRNA (D-001810-10; Thermo Fisher Scientific, Waltham, MA, USA). RNAs were incubated with OPTI-MEM and Lipofectamine RNAiMAX Reagent (both from Invitrogen) as described previously (9-11).

Cell proliferation, migration, and invasion assays. Cells were transfected with $10 \mathrm{nM}$ miRNAs by reverse transfection and plated in 96-well plates at $8 \times 10^{3}$ cells/well. After $96 \mathrm{~h}$, cell proliferation was determined with the XTT assay using the Cell Proliferation kit II (Roche Molecular Biochemicals, Mannheim, Germany) as described previously (9-11).

Cell migration activity was evaluated with wound healing assays. Cells were plated in 6 -well plates at $8 \times 10^{5}$ cells/well, and after $48 \mathrm{~h}$ of transfection, the cell monolayer was scraped using a P-20 micropipette tip. The initial gap length $(0 \mathrm{~h})$ and the residual gap length $24 \mathrm{~h}$ after wounding were calculated from photomicrographs as described previously (9-11).

Cell invasion assays were performed using modified Boyden chambers, consisting of Transwell-precoated Matrigel membrane filter inserts with $8 \mu \mathrm{m}$ pores in 24-well tissue culture plates (BD Biosciences, Bedford, MA, USA). After $72 \mathrm{~h}$ of transfection, cells were plated in 24-well plates at $1 \times 10^{5}$ cells/well. Minimum essential medium containing $10 \%$ FBS in the lower chamber served as the chemoattractant, as described previously (9-11). All experiments were performed in triplicate.

Western blotting. After $96 \mathrm{~h}$ of transfection, protein lysates $(50 \mu \mathrm{g})$ were separated on NuPAGE on 4-12\% Bis-Tris gels (Invitrogen) and transferred to polyvinylidene fluoride membranes. Immunoblotting was performed with diluted antiLOXL2 antibodies (1:1,000; ab96233; Abcam, Cambridge, UK) and anti-GAPDH antibodies (1:5,000; MAB374; Chemicon, Temecula, CA, USA). The membrane was washed and then incubated with an anti-rabbit-IgG, HRP-linked antibody (\#7074; Cell Signaling Technology, Danvers, MA, USA). 
Table I. Characteristics of the lung cancer and normal lung cases.

A, Characteristics of the lung cancer cases

\begin{tabular}{lrr}
\hline Lung cancer & $\mathrm{n}$ & $(\%)$ \\
\hline Total number & 32 & \\
Median age (range) & 71 & $(50-88)$ \\
Gender & & \\
Male & 30 & $(93.7)$ \\
Female & 2 & $(6.3)$
\end{tabular}

Pathological stage

$\begin{array}{lll}\mathrm{I}_{\mathrm{A}} & 4 & (12.5) \\ \mathrm{I}_{\mathrm{B}} & 8 & (25.0) \\ \mathrm{II}_{\mathrm{A}} & 4 & (12.5) \\ \mathrm{II}_{\mathrm{B}} & 5 & (15.6) \\ \mathrm{III}_{\mathrm{A}} & 8 & (25.0) \\ \mathrm{III}_{\mathrm{B}} & 1 & (3.1) \\ \text { Unknown } & 2 & (6.3)\end{array}$

Differentiation

Well 8

Moderately 19

Poorly

Unknown

Pleural invasion

$(+)$

$(-)$

Venous invasion

$\begin{array}{ll}(+) & 16 \\ (-) & 16\end{array}$

Lymphatic invasion

$\begin{array}{ll}(+) & 16 \\ (-) & 16\end{array}$

Recurrence

\begin{tabular}{lrr}
$(+)$ & 9 & $(28.1)$ \\
$(-)$ & 20 & $(62.5)$ \\
Unknown & 3 & $(9.4)$ \\
\hline
\end{tabular}

$\mathrm{B}$, Characteristics of the normal lung cases

\begin{tabular}{lcc}
\hline Normal lung & $\mathrm{n}$ & $(\%)$ \\
\hline Total number & 22 & \\
Median age (range) & 71 & $(50-88)$ \\
Gender & & \\
Male & 22 & \\
Female & 0 \\
\hline
\end{tabular}

Specific complexes were visualized with an echochemiluminescence (ECL) detection system (GE Healthcare, Little Chalfont, UK) as described previously (9-11).
Plasmid construction and dual-luciferase reporter assay. A partial wild-type sequence of the LOXL2 3'-UTR or those with a deleted miR-29 target site (position 555-561 or position 757-763 of the LOXL2 3'-UTR) was inserted between the XhoI-PmeI restriction sites in the 3'-UTR of the hRluc gene in the psiCHECK-2 vector (C8021; Promega, Madison, WI, USA).

The synthesized DNA was cloned into the psiCHECK-2 vector. EBC-1 cells and SK-MES-1 cells were transfected with a $50 \mathrm{ng}$ vector, $10 \mathrm{nM}$ miRNAs, and $1 \mu \mathrm{l}$ of Lipofectamine 2000 in $100 \mu \mathrm{l}$ of Opti-MEM (both from Invitrogen). The activities of Firefly and Renilla luciferases in cell lysates were determined with a dual-luciferase assay system (E1910; Promega). Normalized data were calculated as the quotient of Renilla/Firefly luciferase activities.

Immunohistochemistry. We stained the tissue array (LC2083; US Biomax, Rockville, MD, USA). The tissues were immunostained following the manufacturer's protocol with an UltraVision Detection System (Thermo Fisher Scientific). The primary rabbit polyclonal antibodies against LOXL2 (ab96233) were diluted 1:1,000. The slides were treated with biotinylated goat anti-rabbit antibodies. Diaminobenzidine hydrogen peroxidase was the chromogen, and counterstaining was done with $0.5 \%$ hematoxylin.

Identification of putative miR-29 target genes. To identify putative $m i R$-29-regulated genes, we used the TargetScan database (http://www.targetscan.org/). We investigated the expression status of putative targets of $m i R-29$ using lung SCC clinical expression data from the GEO database (accession no. GSE 11117). Additionally, we performed gene expression analysis using $m i R-29 a$ transfected EBC-1 cells. Oligo-microarray procedures and data mining methods were described in previous studies $(9,10)$.

Statistical analysis. Relationships between two or three variables and numerical values were analyzed using the Mann-Whitney U test or Bonferroni-adjusted Mann-Whitney U test. Expert StatView version 4 was used in these analyses.

\section{Results}

Expression levels of $m i R-29 a, m i R-29 b$ and $m i R-29 c$ in lung SCC clinical specimens. The expression levels of miR-29a, $m i R-29 b$ and $m i R-29 c$ were significantly reduced in tumor tissues compared to corresponding noncancerous tissues $(\mathrm{P}<0.0001$, $\mathrm{P}=0.0031$ and $\mathrm{P}<0.0001$, respectively) (Fig. 1A-C). Spearman's rank test showed a positive correlation between the expression of $m i R-29 a$ and that of $m i R-29 b(\mathrm{R}=0.836$ and $\mathrm{P}<0.0001)$ (Fig. 1D). The expression of $m i R-29 a$ was positively correlated with that of $m i R-29 c(\mathrm{R}=0.878$ and $\mathrm{P}<0.0001)$ (Fig. 1E). Similarly, the expression of $m i R-29 b$ was positively correlated with that of $m i R-29 c(\mathrm{R}=0.744$ and $\mathrm{P}<0.0001)$ (Fig. 1F).

Effects of $m i R-29 a, m i R-29 b$ and $m i R-29 c$ restoration on the proliferation, migration and invasion in lung SCC cell lines. To examine the functional roles of the $m i R-29$ family ( $m i R-29 a$, $m i R-29 b$ and $m i R-29 c$ ), we performed gain-of-function studies using miRNA transfection into lung SCC cell lines (EBC-1 and SK-MES-1). 

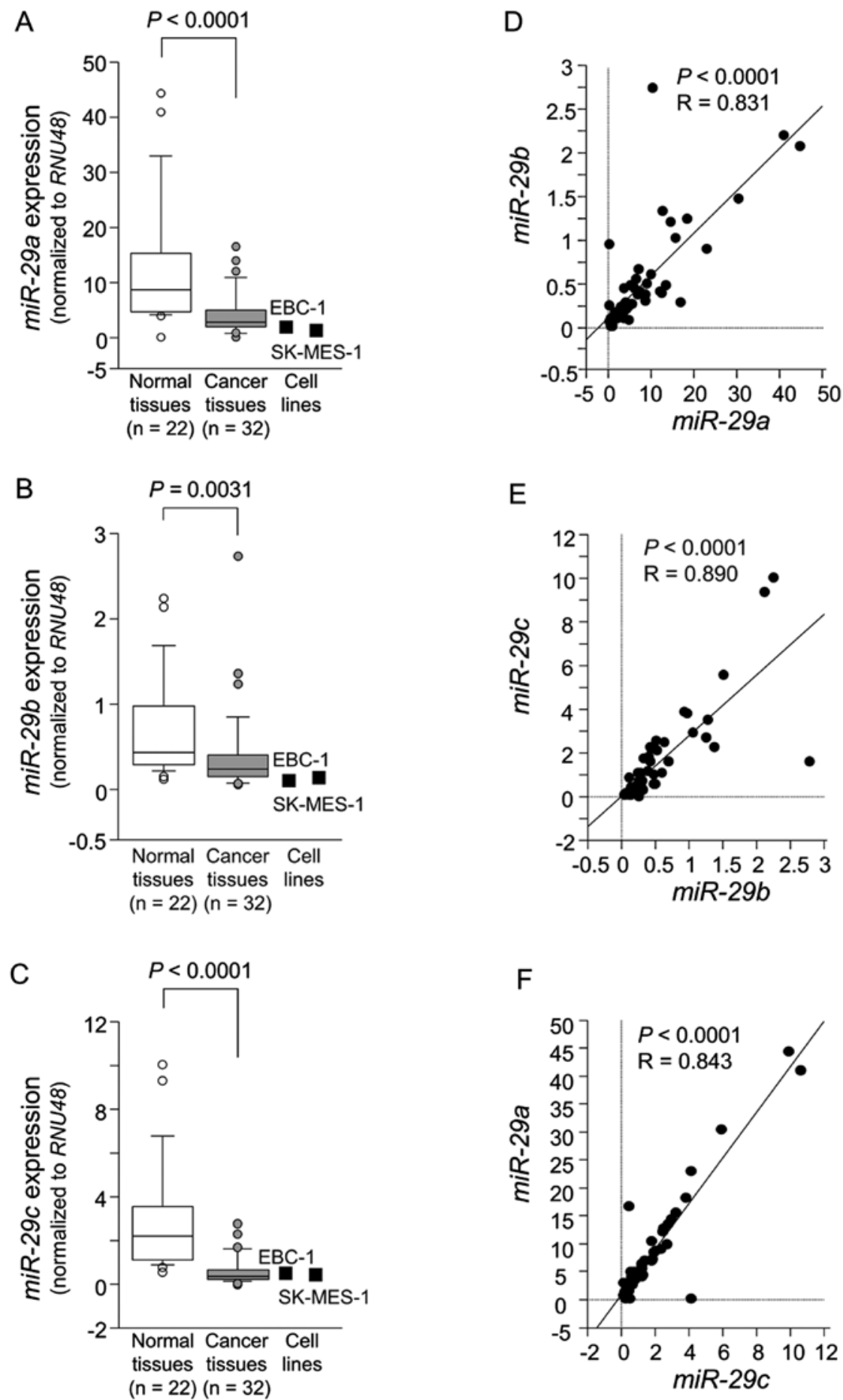

Figure 1. The expression levels of $m i R-29 a, m i R-29 b$ and $m i R-29 c$ in clinical specimens and cell lines. Real-time PCR showed that the expression levels of (A) $m i R-29 a$, (B) $m i R-29 b$ and (C) $m i R-29 c$ were significantly lower in lung SCC tissues than in normal lung tissues $(\mathrm{P}<0.0001$, $\mathrm{P}=0.0031$ and $\mathrm{P}<0.0001$, respectively). RNU48 was used as an internal control. Correlations between (D) $m i R-29 a-m i R-29 b,(\mathrm{E}) m i R-29 b-m i R-29 c$ and (F) $m i R-29 c-m i R-29 a$ were determined in lung SCC clinical specimens.

XTT assays revealed significant inhibition of cell proliferation in SK-MES-1 cells transfected with $m i R$ - 29 s in comparison with mock or control transfectants $(\mathrm{P}<0.0001)$ (Fig. 2A). Otherwise, in EBC-1 cells transfected with $m i R-29 s$, there was no significant inhibition of cell proliferation in comparison with control transfectants (Fig. 2A).

Wound healing assays showed significant inhibition of cell migration activity after transfection with $m i R-29 \mathrm{~s}$ $(\mathrm{P}<0.0001)$ (Fig. 2B).
Similarly, Matrigel invasion assays revealed that transfection with $m i R-29$ reduced cell invasion activities $(\mathrm{P}<0.0001)$ (Fig. 2C).

Identification of candidate target genes of miR-29s in lung SCC. To identify molecular targets of $m i R-29 s$, we used a combination of in silico analysis and lung SCC gene expression data. In total, 2,627 genes were putative targets of $m i R-29 \mathrm{~s}$ according to the TargetScan database. Next, we pared down the list of 
A

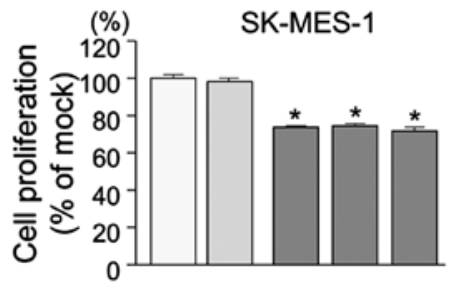

B

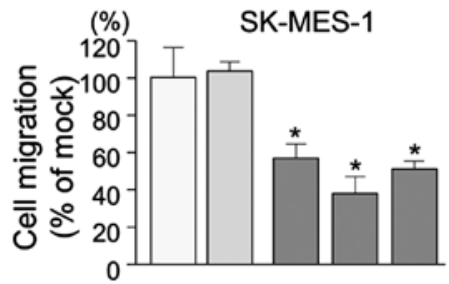

C

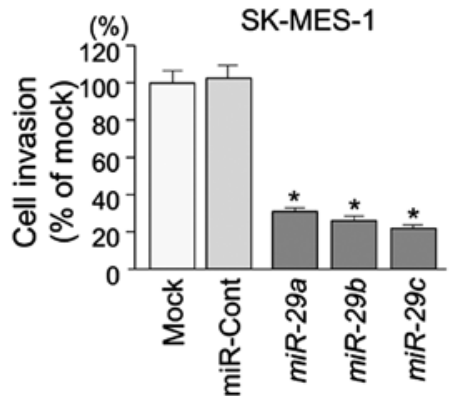

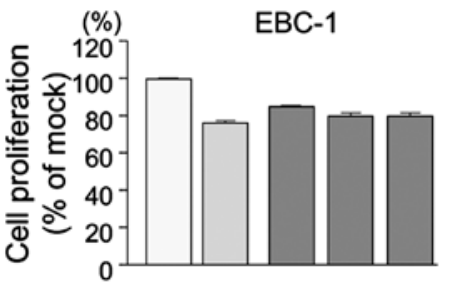
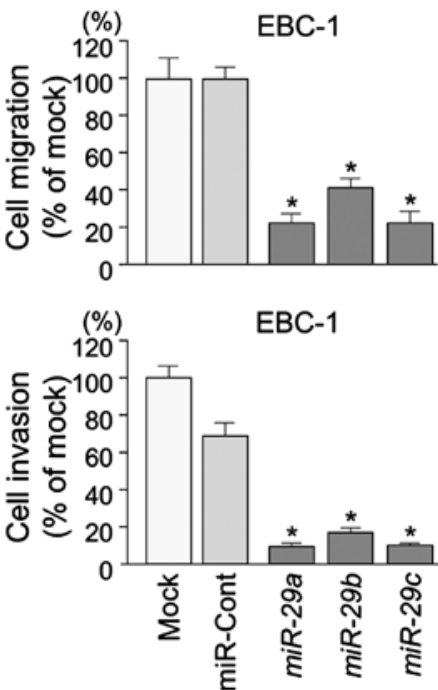

Figure 2. Effects of $m i R-29 a, m i R-29 b$ and $m i R-29 c$ transfection on SK-MES-1 and EBC-1 cells. (A) Cell proliferation was determined with XTT assays 96 h after transfection with $10 \mathrm{nM} m i R-29 \mathrm{~s}$, miR-control, or mock transfection. (B) Cell migration activity was determined by migration assay $48 \mathrm{~h}$ after transfection. (C) Cell invasion activity was determined by Matrigel invasion assay $72 \mathrm{~h}$ after transfection. ${ }^{*} \mathrm{P}<0.0001$.

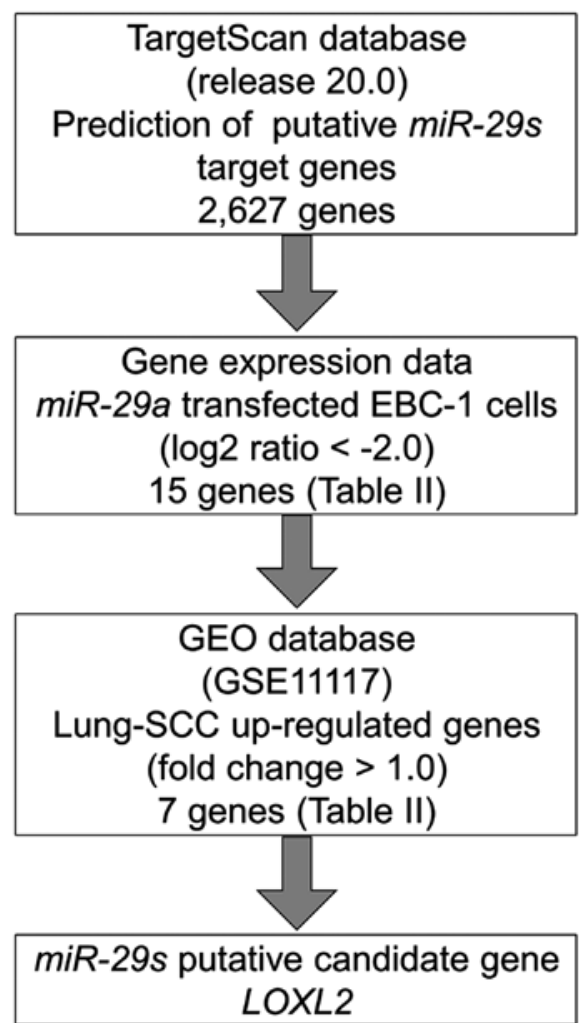

Figure 3. Flow chart of the strategy for identification of $m i R-29$ target genes. In total, 2,627 genes were putative targets of $m i R-29 s$ according to the TargetScan database. We merged the expression analysis data of downregulated genes in miR-29a-transfected EBC-1 cells $\left(\log _{2}\right.$ ratio <-2.0). Upregulated genes were determined according to the gene expression data set of lung SCC clinical specimens according to the GEO database (accession no. GSE 11117). From this selection, 7 candidate genes were identified as targets of the miR-29s. genes based on two kinds of gene expression data: downregulated genes $\left(\log _{2}\right.$ ratio $\left.<-2.0\right)$ following $m i R$-29a-transfected EBC-1 cells and upregulated genes determined by the gene expression data set of lung SCC clinical specimens according to the GEO database (accession no. GSE 11117). From this selection, 7 candidate genes were identified as targets of the $m i R-29 s$ (Table II). Among these genes, we focused on the LOXL2 gene and examined the LOXL2 function and characteristics in further analyses. Our strategy for selecting $m i R-29$ target genes is shown in Fig. 3.

LOXL2 is directly regulated by miR-29s in lung SCC cells. We performed qRT-PCR and western blotting to confirm LOXL2 downregulation following restoration of $m i R-29 s$ expression in lung SCC cell lines. The mRNA and protein expression levels of LOXL2 were significantly repressed in $m i R-29 s$ transfectants in comparison with mock or miR-control transfectants $(\mathrm{P}<0.001)$ (Fig. 4).

The TargetScan database identified two putative target sites in the 3'-UTR of LOXL2 (Fig. 5, upper part). A luciferase reporter assay confirmed that the 3'-UTR of LOXL2 was indeed an actual target of $m i R-29 \mathrm{~s}$. Luciferase activity was significantly decreased in two miR-29 target sites (positions 555-561 and 757-763 in the 3'-UTR of LOXL2) (Fig. 5, lower part).

Effects of downregulating LOXL2 on cell proliferation, migration, and invasion in lung SCC cell lines. To investigate the functional role of $L O X L 2$ in lung SCC cells, we performed loss-of-function studies using si-LOXL2 transfectants. First, we evaluated the knockdown efficiency of si-LOXL2 transfection 
Table II. Downregulated genes in miR-29a transfectant.

\begin{tabular}{|c|c|c|c|c|c|c|}
\hline $\begin{array}{l}\text { Entrez } \\
\text { gene ID }\end{array}$ & $\begin{array}{l}\text { Gene } \\
\text { symbol }\end{array}$ & Description & $\begin{array}{c}\text { EBC-1 } \\
m i R-29 \\
\text { transfectant } \\
\log _{2} \text { ratio }\end{array}$ & $\begin{array}{l}\text { miR-29a } \\
\text { conserved } \\
\quad \text { site }\end{array}$ & $\begin{array}{l}\text { miR-29a } \\
\text { poorly } \\
\text { conserved } \\
\text { site }\end{array}$ & $\begin{array}{l}\text { GSE1117 } \\
\text { fold-change }\end{array}$ \\
\hline 4017 & LOXL2 & Lysyl oxidase-like 2 & -4.05 & 1 & 1 & 2.10 \\
\hline 3038 & $H A S 3$ & Hyaluronan synthase 3 & -3.37 & 3 & & 4.19 \\
\hline 9535 & $G M F G$ & Glia maturation factor $\gamma$ & -3.10 & 2 & & ND \\
\hline 3655 & ITGA6 & Integrin $\alpha 6$ & -2.62 & 1 & & 2.78 \\
\hline 634 & CEACAM1 & $\begin{array}{l}\text { Carcinoembryonic antigen-related cell } \\
\text { adhesion molecule } 1 \text { (biliary glycoprotein) }\end{array}$ & -2.58 & 1 & 1 & 1.41 \\
\hline 871 & SERPINHI & $\begin{array}{l}\text { Serpin peptidase inhibitor, clade } \mathrm{H} \\
\text { (heat shock protein } 47 \text { ), } \\
\text { member } 1 \text { (collagen binding protein } 1 \text { ) }\end{array}$ & -2.57 & 1 & & ND \\
\hline 22801 & ITGAII & Integrin $\alpha 11$ & -2.42 & 1 & & 1.50 \\
\hline 80381 & $C D 276$ & CD276 molecule & -2.35 & 1 & & ND \\
\hline 50848 & F11R & F11 receptor & -2.26 & 1 & 1 & ND \\
\hline 8894 & $E I F 2 S 2$ & $\begin{array}{l}\text { Eukaryotic translation initiation factor } 2 \text {, } \\
\text { subunit } 2 \beta, 38 \mathrm{kDa}\end{array}$ & -2.17 & 1 & 1 & 1.70 \\
\hline 91584 & PLXNA4 & Plexin A4 & -2.15 & 1 & 1 & ND \\
\hline 55920 & $R C C 2$ & Regulator of chromosome condensation 2 & -2.11 & 1 & & ND \\
\hline 9076 & CLDN1 & Claudin 1 & -2.10 & 1 & & ND \\
\hline 2118 & ETV4 & Ets variant 4 & -2.09 & 1 & & 4.84 \\
\hline 284119 & PTRF & Polymerase I and transcript release factor & -2.05 & 1 & & -1.86 \\
\hline
\end{tabular}

ND, no data.

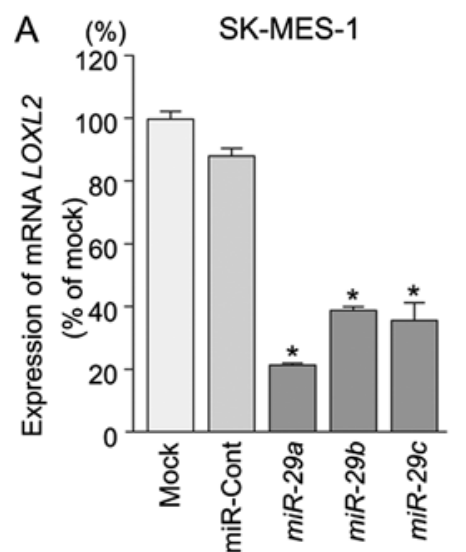

B

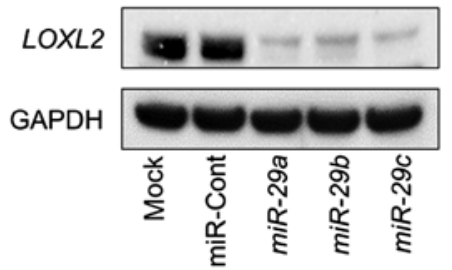

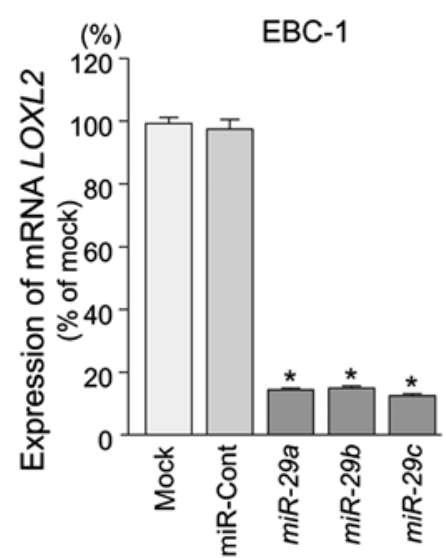

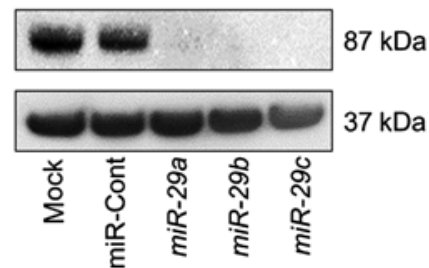

Figure 4. Direct regulation of $L O X L 2$ by $m i R-29 s$ in SK-MES-1 and EBC-1 cells. (A) LOXL2 mRNA expression was evaluated by qRT-PCR 72 h after transfection with $m i R-29 s$. GUSB was used as an internal control. (B) LOXL2 protein expression was evaluated by western blotting $96 \mathrm{~h}$ after transfection with $m i R-29 s$. GAPDH was used as a loading control.

in lung SCC cells. Western blotting and qRT-PCR indicated that si-LOXL2 effectively downregulated LOXL2 expression in lung SCC cells $(\mathrm{P}<0.0001)$ (Fig. 6).
XTT assays demonstrated that cell proliferation was not inhibited in si-LOXL2 transfectants in comparison with mock or si-control transfectants in lung SCC cells (Fig. 7A). 
A Position 555-561 of LOXL2 3'UTR

5' '... UGGUGAGCUCAGACUUGGUGCUU -3' Wild

3' AUUGGCUAAAGUCU---ACCACGAU..5' miR-29a

5' $\cdots$ UgGUGAGCUCAGACUUGGUGCUU • 3 ' Wild

3' UUGUGACUAAAGUUUACCACGAU ..5' miR-29b

5' ' '. UGGUGAGCUCAGACUUGGUGCUU -3' Wild

3' AUUGGCUAAAGUUUACCACGAU..5' miR-29c

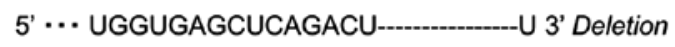
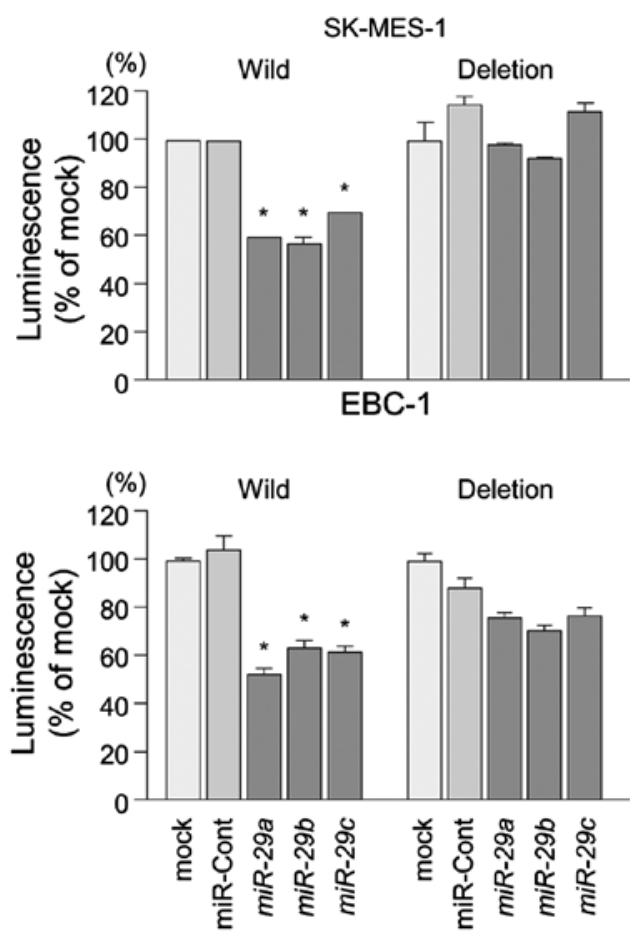

\section{B Position 757-763 of LOXL2 3'UTR}

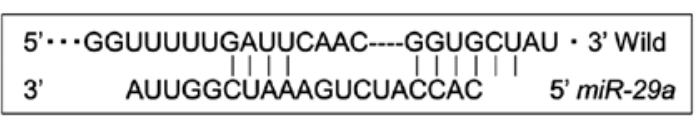

5'.-.GGUUUUUGAUUCAAC---GGUGCUAU · 3' Wild

3' UUGUGACUAAAGUUUACCACGAU 5' miR-29b

5'.'-GGUUUUUGAUUCAAC--GGUGCUAU · 3' Wild

3' AUUGGCUAAAGUUUACCACGAU 5' miR-29c

5' ... GGUUUUUGAUUCAAC---.--.-----AU 3' Deletion
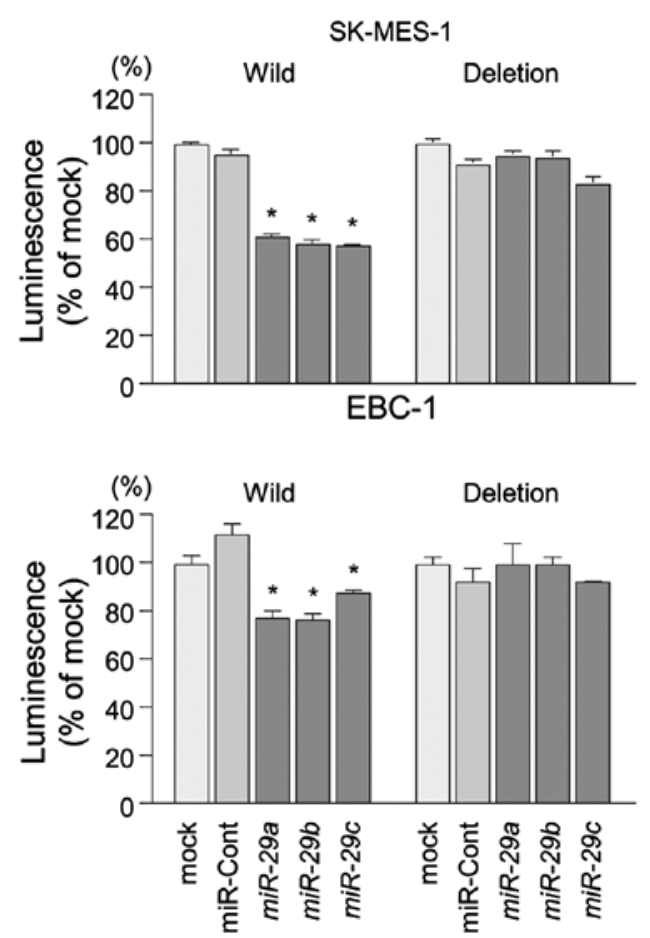

Figure 5. Direct regulation of $L O X L 2$ by $m i R-29 s$ in lung SCC cells. A luciferase reporter assay using vectors encoding putative $m i R-29$ target sites at positions (A) 555-561 and (B) 757-763 for both wild-types and deletion types, respectively. Renilla luciferase values were normalized to Firefly luciferase values. ${ }^{*} \mathrm{P}<0.0001$.

Wound healing assays showed significant inhibition of cell migration in si-LOXL2 transfectants in comparison with mock or si-control transfectants in lung SCC cells $(\mathrm{P}<0.0001)$ (Fig. 7B).

Similarly, Matrigel invasion assays revealed that the number of invading cells was significantly decreased when lung SCC cells were transfected with si-LOXL2 $(\mathrm{P}<0.0001)($ Fig. 7C).

Immunohistochemical staining of LOXL2 in lung SCC clinical specimens. We confirmed the expression status of LOXL2 in lung SCC clinical specimens using immunohistochemical staining. Fifty specimens were checked in this study: 32 of 40 lung SCC specimens stained moderately or strongly, and 9 of 10 normal lung specimens stained weakly or negatively for LOXL2 (Table III and Fig. 8).

\section{Discussion}

Recent studies have suggested that the interaction of cancer cells with their microenvironment has influenced the initiation, development, and metastasis of tumors $(19,20)$. Overexpression of extracellular matrix (ECM) components has frequently been observed in cancer lesions and aberrantly expressed ECM-mediated signals have triggered cancer cell metastasis $(21,22)$. Our past studies demonstrated that $m i R-29 \mathrm{~s}$ and $m i R-218$ directly regulated laminin-integrin signaling and thereby activated cancer cell migration and invasion (23-25). Other studies indicated that $m i R-29$ s modulated ECM components such as collagen, laminin and elastin (26). Therefore, the identification of ECM-regulated tumor-suppressive miRNAs may provide a better appreciation of novel pathways and how their interrelations are involved in cancer metastasis.

Our present data showed that all members of the miR-29 family were significantly reduced in lung SCC specimens. Our previous studies also showed the downregulation of $m i R-29 \mathrm{~s}$ in renal cell carcinoma, cervical cell carcinoma, and head and neck squamous cell carcinoma $(24,25,27,28)$ and are consistent with present data on lung SCC. However, the molecular mechanisms underlying the dysregulated expression of the miR-29s in lung SCC cells are still unclear. The genomic structure 

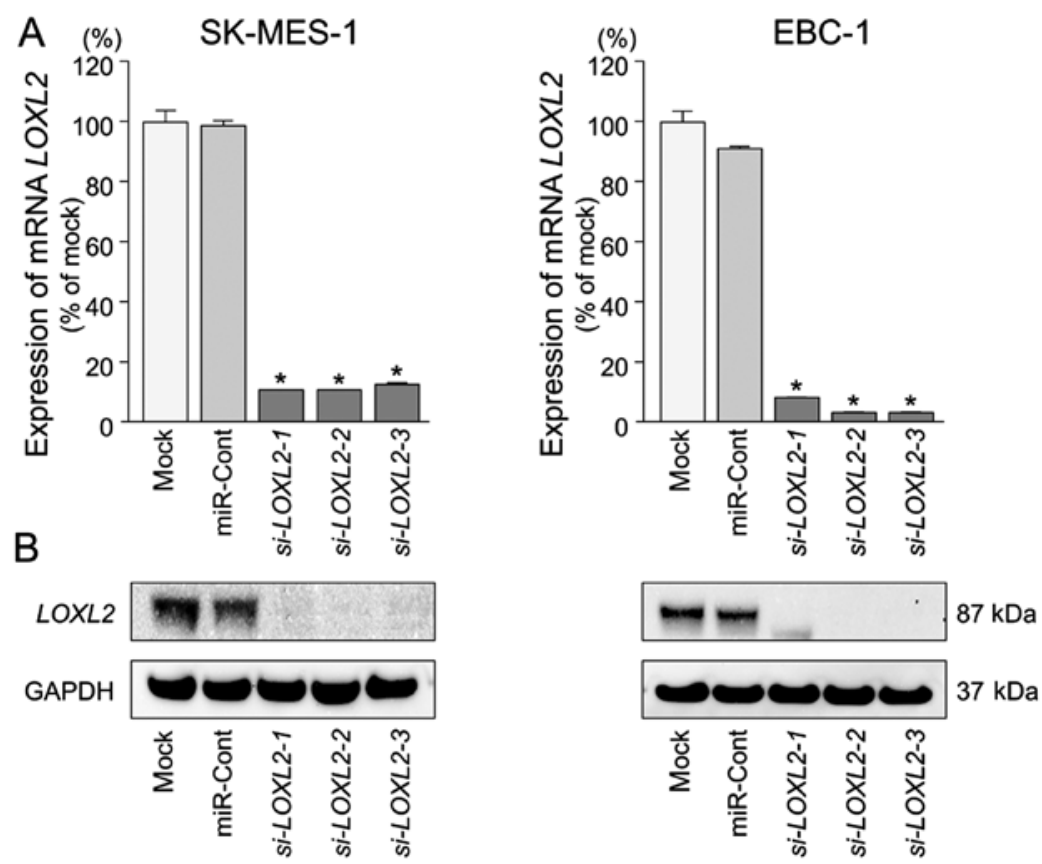

Figure 6. Silencing of $L O X L 2$ by using si-LOXL2 in lung SCC cells. Silencing of LOXL2 mRNA and protein expression by si-LOXL2 transfection and the effects of the silencing of $L O X L 2$ on SK-MES-1 and EBC-1 cell activities. (A) LOXL2 mRNA expression was evaluated by qRT-PCR $72 \mathrm{~h}$ after transfection with $m i R-29 s$. GUSB was used as an internal control. "P<0.0001. (B) LOXL2 protein expression was evaluated by western blotting $96 \mathrm{~h}$ after transfection. GAPDH was used as a loading control.
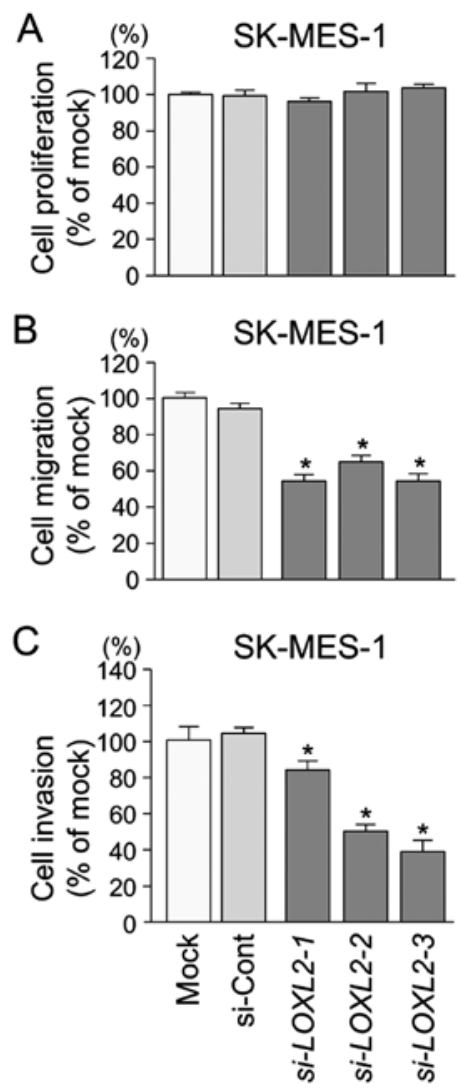
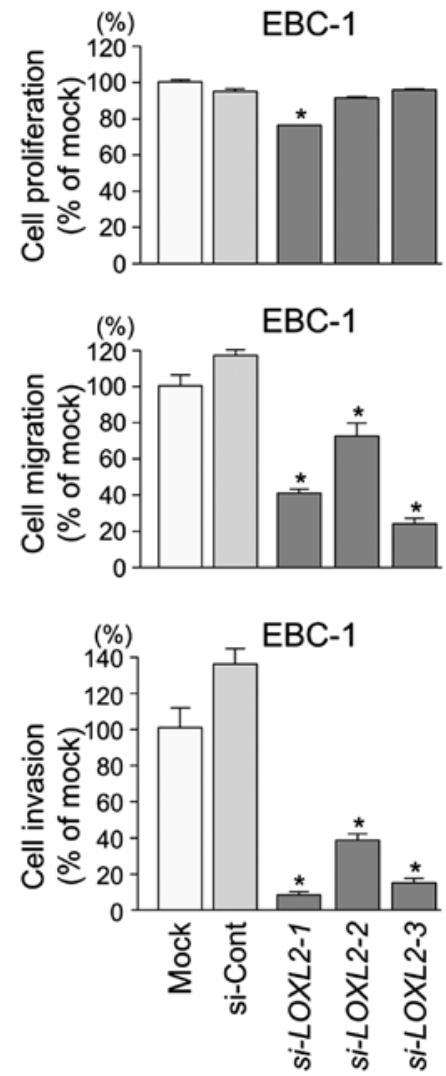

Figure 7. Effects of $s i-L O X L 2$ transfection on lung SCC cell lines. (A) Cell proliferation was determined using XTT assays $96 \mathrm{~h}$ after transfection with $10 \mathrm{nM}$ si-LOXL2, miR-control, or mock transfection. (B) Cell migration activity was determined by migration assay $48 \mathrm{~h}$ after transfection. (C) Cell invasion activity was determined by Matrigel invasion assay $72 \mathrm{~h}$ after transfection. ${ }^{*} \mathrm{P}<0.0001$.

of the $m i R-29$ family consists of two clusters in the human genome: $m i R-29 b-1$ and $m i R-29 a$ in $7 \mathrm{q} 32$ and $m i R-29 b-2$ and $m i R-29 c$ in $1 \mathrm{q} 32(26)$. Several studies indicated the molecular mechanisms of the silencing of $m i R-29 s$ (26). Previous studies 

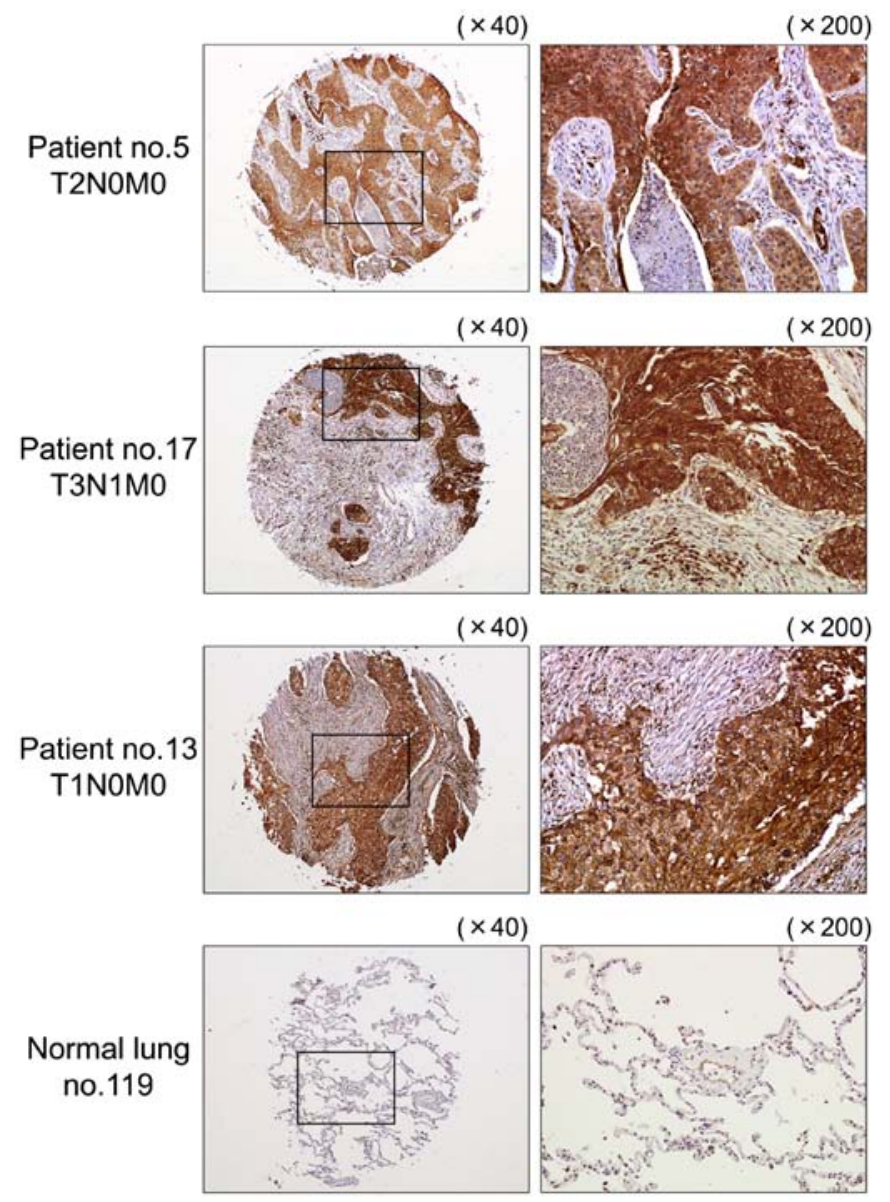

Figure 8. Immunohistochemical staining of LOXL2 in lung SCC specimens Differences in LOXL2 expression are observed in cancer lesions and adjacent non-cancerous tissues in the same fields. Normal lung specimens stained negatively.

demonstrated that the promoter regions of $m i R-29 b-1 / m i R-29 a$ showed that two putative E-box (MYC-binding) sites, a Gli-binding site and four NF- $\mathrm{NB}$-binding sites, were contained within this region, and c-Myc and NF- $\mathrm{B}$ suppressed miR-29 expression at transcriptional levels (29). A recent study showed that cancer cells with high $c-M y c$, low $m i R-29 b$, and low FHIT expression had a shorter overall survival and relapse-free survival in NSCLC patients (30). In breast cancer, GATA3 is a transcription factor that specifies and maintains luminal epithelial cell differentiation in the mammary gland (31). Loss of GATA3 is involved in breast cancer pathogenesis (31). The miR-29a/miR-29b-1 promoter region contains three GATA3binding sites, and GATA3 induced $m i R-29 b$ expression, which inhibits metastasis by targeting metastatically involved genes (31). Moreover, recent data have suggested that TGF- $\beta$ inhibited the expression of $m i R-29 \mathrm{~s}$ and promoted the expression of ECM components $(32,33)$. However, the silencing of molecular mechanisms of $m i R-29 \mathrm{~s}$ in lung SCC are still unclear; detailed examination will be necessary to better understand these processes.

In this study, the restoration of $m i R-29 s$ into cancer cells significantly inhibited migration and invasion; thus miR-29-mediated novel targets deeply contribute to metastatic pathways. To better understand lung SCC metastasis, we searched putative $m i R$-29-regulated genes by using gene
Table III. Immunohistochemistry status and characteristics of the lung cancer and normal lung cases.

A, Immunohistochemistry status and characteristic of the lung cancer cases

\begin{tabular}{|c|c|c|c|c|c|c|}
\hline $\begin{array}{l}\text { Patient } \\
\text { no. }\end{array}$ & Grade & $\mathrm{T}$ & $\mathrm{N}$ & M & $\begin{array}{c}\text { Pathological } \\
\text { stage }\end{array}$ & $\begin{array}{l}\text { Immuno- } \\
\text { histochemistry }\end{array}$ \\
\hline 1 & 1 & 3 & 1 & 0 & $\mathrm{III}_{\mathrm{A}}$ & $(++)$ \\
\hline 2 & 2 & 2 & 1 & 0 & $\mathrm{II}_{\mathrm{A}}$ & $(++)$ \\
\hline 3 & 2 & 2 & 0 & 0 & $\mathrm{I}_{\mathrm{B}}$ & $(+)$ \\
\hline 4 & 2 & 2 & 0 & 0 & $\mathrm{I}_{\mathrm{B}}$ & $(+++)$ \\
\hline 5 & 2 & 2 & 0 & 0 & $\mathrm{I}_{\mathrm{B}}$ & $(+++)$ \\
\hline 6 & 2 & 2 & 1 & 0 & $\mathrm{II}_{\mathrm{B}}$ & $(++)$ \\
\hline 7 & 2 & 3 & 2 & 0 & $\mathrm{III}_{\mathrm{A}}$ & $(+++)$ \\
\hline 8 & 2 & 2 & 0 & 0 & $I^{\mathrm{A}}$ & $(++)$ \\
\hline 9 & 2 & 2 & 2 & 0 & $\mathrm{III}_{\mathrm{A}}$ & $(+)$ \\
\hline 10 & 2 & 2 & 2 & 0 & $\mathrm{III}_{\mathrm{A}}$ & $(+)$ \\
\hline 11 & 2 & 2 & 2 & 0 & $\mathrm{III}_{\mathrm{A}}$ & $(+)$ \\
\hline 12 & 2 & 3 & 0 & 0 & $\mathrm{II}_{\mathrm{B}}$ & $(+)$ \\
\hline 13 & 2 & 1 & 0 & 0 & $\mathrm{I}_{\mathrm{A}}$ & $(+++)$ \\
\hline 14 & 2 & 2 & 0 & 0 & I & $(++)$ \\
\hline 15 & 2 & 2 & 1 & 0 & $\mathrm{II}_{\mathrm{B}}$ & $(++)$ \\
\hline 16 & 2 & 2 & 1 & 0 & $\mathrm{I}_{\mathrm{B}}^{\mathrm{D}}$ & $(++)$ \\
\hline 17 & 2 & 3 & 1 & 0 & $\mathrm{III}_{\mathrm{A}}$ & $(+++)$ \\
\hline 18 & 2 & 2 & 0 & 0 & $\mathrm{I}_{\mathrm{B}}$ & $(++)$ \\
\hline 19 & 2 & 3 & 1 & 0 & $\mathrm{III}_{\mathrm{A}}$ & $(+++)$ \\
\hline 20 & 2 & 2 & 0 & 0 & $\mathrm{I}_{\mathrm{B}}$ & $(++)$ \\
\hline 21 & 3 & 2 & 0 & 0 & $\mathrm{I}_{\mathrm{B}}$ & $(+)$ \\
\hline 22 & 3 & 2 & 1 & 0 & II & $(++)$ \\
\hline 23 & 3 & 2 & 0 & 0 & $\mathrm{I}_{\mathrm{B}}$ & $(++)$ \\
\hline 24 & 3 & 2 & 0 & 0 & $\mathrm{I}_{\mathrm{B}}$ & $(++)$ \\
\hline 25 & 3 & 2 & 0 & 0 & $\mathrm{I}_{\mathrm{B}}$ & $(+++)$ \\
\hline 27 & 3 & 3 & 2 & 0 & $\mathrm{III}_{\mathrm{A}}$ & $(++)$ \\
\hline 28 & 3 & 2 & 0 & 0 & $\mathrm{I}_{\mathrm{B}}$ & $(+++)$ \\
\hline 29 & 2 & 3 & 1 & 0 & $\mathrm{III}_{\mathrm{A}}$ & $(+++)$ \\
\hline 30 & 3 & 3 & 1 & 0 & IIIA & $(++)$ \\
\hline 31 & 3 & 2 & 0 & 0 & $\mathrm{I}_{\mathrm{B}}$ & $(++)$ \\
\hline 32 & 3 & 3 & 1 & 0 & $\mathrm{III}_{\mathrm{A}}$ & $(++)$ \\
\hline 33 & 3 & 2 & 1 & 0 & $\mathrm{II}_{\mathrm{A}}$ & $(++)$ \\
\hline 34 & 3 & 1 & 2 & 0 & $\mathrm{III}_{\mathrm{A}}$ & $(++)$ \\
\hline 35 & 3 & 2 & 2 & 0 & $\mathrm{III}_{\mathrm{A}}$ & $(+)$ \\
\hline 36 & 3 & 2 & 0 & 0 & I & $(+)$ \\
\hline 37 & & 2 & 0 & 0 & $\mathrm{I}_{\mathrm{B}}$ & $(+++)$ \\
\hline 38 & 3 & 2 & 0 & 0 & $\mathrm{I}_{\mathrm{B}}$ & $(++)$ \\
\hline 39 & 3 & 2 & 0 & 0 & $\mathrm{I}_{\mathrm{B}}$ & $(+++)$ \\
\hline 40 & 3 & 1 & 0 & 0 & $\mathrm{I}_{\mathrm{A}}$ & $(+++)$ \\
\hline 41 & 3 & 2 & 0 & 0 & $\mathrm{I}_{\mathrm{B}}^{\mathrm{A}}$ & $(++)$ \\
\hline
\end{tabular}

B, Immunohistochemistry status of normal lung cases

Patient no.

Immunohistochemistry

111

$(+)$

112

$(+)$

113

$(-)$

114

$(++)$

115

$(-)$

116

$(+)$

117

(+)

118

(-)

119

(-)

120 
expression analysis combined with in silico analysis. Finally, 15 putative candidate genes were listed in this analysis. Among these genes, integrin $\alpha 6$ (ITGA6) and serpin peptidase inhibitor, clade $\mathrm{H}$, member 1 (SERPINHI) have already been reported by our group as $m i R$-29-regulated genes in head and neck squamous cell carcinoma and cervical cancer $(24,28)$. Moreover, another group showed that $m i R-29 c$ may be involved in the regulation of cell proliferation through targeting regulator of chromosome condensation 2 (RCC2) in gastric carcinoma (34). The target gene list provided by this analysis is effective for $m i R$-29-regulated target analysis.

Here, we focused on the LOXL2 gene and validated the direct regulation of $m i R-29 \mathrm{~s}$ in lung SCC cells. Furthermore, overexpression of LOXL2 was detected in lung SCC clinical specimens, and silencing of $L O X L 2$ expression in lung $\mathrm{SCC}$ cells inhibited cancer cell migration and invasion, indicating that $L O X L 2$ acts as an oncogene in the disease. Interestingly, our latest data on renal cell carcinoma also showed that $L O X L 2$ was a direct regulator of tumor-suppressive $m i R-29 s$ (27). The lysyl oxidase (LOX) protein family comprises LOX and four LOX-like proteins (LOXL1-LOXL4). These proteins are copper- and quinone-dependent amino oxidases (35). Basically, the function of the LOX family is the covalent crosslinking of collagen and/or elastin in the ECM (36-38). Several studies suggested that LOXL2-mediated cancer progression cause ECM modification and increased ECM deposition, and subsequent tissue stiffness derives malignant progression through activation of ECM-integrin or ECM-growth factor signaling (39-42). It has been reported that overexpression of LOXL2 in a number of cancers and high expression levels of LOXL2 are correlated with cancer cell invasion, lymph node metastasis, and poor overall patient survival in patients with gastric cancer, breast cancer and squamous cell carcinomas (43-45).

It is well known that metastasis is associated with the aberrant activation of epithelial-mesenchymal transition (EMT)-related transcriptional factors and TGF- $\beta$ signaling, which endows cancer cells with elevated capabilities to invade and disseminate to distant sites (46). Previous studies have shown that LOXL2 is a direct transcriptional target of HIF1 (46). Moreover, nuclear LOXL2 interacts with transcription factor SNAIL1 and represses E-cadherin as well as inducing EMT $(47,48)$. These findings suggest that hypoxia conditions and overexpression of LOXL2 trigger the ability for metastasis acquisition of the cancer cells. Several studies indicated that targeting LOXL2 with antibodies inhibited primary and metastatic xenograft models of cancers via suppression of SRC/FAK signaling or the production of growth factors and cytokines and TGF- $\beta$ pathways $(49,50)$. Interestingly, recent data indicated that expression of the LOX family was induced by TGF- $\beta(51,52)$. In contrast, TGF- $\beta$ inhibited the expression of $m i R-29 \mathrm{~s}$ and promoted the expression of ECM components $(53,54)$. The present data suggest that the miR-29-LOXL2 axis regulates the cancer cell microenvironment and activates metastatic pathways. Therefore, the miR-29-regulated metastatic pathway is a potential target in the development of novel therapies to treat pathological lung SCC.

In conclusion, downregulation of $m i R-29 s$ was frequently observed in lung SCC clinical specimens, and all members of the miR-29 family act as tumor-suppressive miRNAs in this disease. $L O X L 2$ was a direct regulator of $m i R-29 s$ in lung SCC cells. Overexpression of LOXL2 was detected in lung SCC clinical specimens, and functional assays showed that $L O X L 2$ promoted cancer cell invasion and migration, indicating this gene as an oncogene in lung SCC cells. The identification of novel molecular pathways mediated by the $m i R-29-L O X L 2$ axis may lead to a better understanding of lung SCC and the development of new therapeutic strategies to treat this disease.

\section{References}

1. Torre LA, Bray F, Siegel RL, Ferlay J, Lortet-Tieulent J and Jemal A: Global cancer statistics, 2012. CA Cancer J Clin 65: 87-108, 2015

2. Travis WD: Pathology of lung cancer. Clin Chest Med 32: 669-692, 2011

3. Reck M,Heigener DF, Mok T, Soria JC and Rabe KF: Management of non-small-cell lung cancer: Recent developments. Lancet 382: 709-719, 2013.

4. Bartel DP: MicroRNAs: Genomics, biogenesis, mechanism, and function. Cell 116: 281-297, 2004.

5. Filipowicz W, Bhattacharyya SN and Sonenberg N: Mechanisms of post-transcriptional regulation by microRNAs: Are the answers in sight? Nat Rev Genet 9: 102-114, 2008.

6. Hobert O: Gene regulation by transcription factors and microRNAs. Science 319: 1785-1786, 2008.

7. Iorio MV and Croce CM: MicroRNAs in cancer: Small molecules with a huge impact. J Clin Oncol 27: 5848-5856, 2009.

8. Fukumoto I, Hanazawa T, Kinoshita T, Kikkawa N, Koshizuka K, Goto Y, Nishikawa R, Chiyomaru T, Enokida H, Nakagawa M, et al: MicroRNA expression signature of oral squamous cell carcinoma: Functional role of microRNA-26a/b in the modulation of novel cancer pathways. Br J Cancer 112: 891-900, 2015.

9. Fukumoto I, Kinoshita T, Hanazawa T, Kikkawa N, Chiyomaru T, Enokida H, Yamamoto N, Goto Y, Nishikawa R, Nakagawa M, et al: Identification of tumour suppressive microRNA-451a in hypopharyngeal squamous cell carcinoma based on microRNA expression signature. Br J Cancer 111: 386-394, 2014.

10. Matsushita R, Seki N, Chiyomaru $\mathrm{T}$, Inoguchi $\mathrm{S}$, Ishihara $\mathrm{T}$, Goto Y, Nishikawa R, Mataki H, Tatarano S, Itesako T, et al: Tumour-suppressive microRNA-144-5p directly targets CCNE1/2 as potential prognostic markers in bladder cancer. Br J Cancer 113: 282-289, 2015.

11. Goto Y, Kojima S, Nishikawa R, Enokida H, Chiyomaru T, Kinoshita T, Nakagawa M, Naya Y, Ichikawa T and Seki N: The microRNA-23b/27b/24-1 cluster is a disease progression marker and tumor suppressor in prostate cancer. Oncotarget 5: 7748-7759, 2014.

12. Mataki H, Enokida H, Chiyomaru T, Mizuno K, Matsushita R, Goto Y, Nishikawa R, Higashimoto I, Samukawa T, Nakagawa M, et al: Downregulation of the microRNA-1/133a cluster enhances cancer cell migration and invasion in lung-squamous cell carcinoma via regulation of Coronin1C. J Hum Genet 60: 53-61, 2015.

13. Mataki H, Seki N, Chiyomaru T, Enokida H, Goto Y, Kumamoto T, Machida K, Mizuno K, Nakagawa M and Inoue H: Tumor-suppressive microRNA-206 as a dual inhibitor of MET and EGFR oncogenic signaling in lung squamous cell carcinoma. Int J Oncol 46: 1039-1050, 2015.

14. Goto Y, Kurozumi A, Enokida H, Ichikawa T and Seki N: Functional significance of aberrantly expressed microRNAs in prostate cancer. Int J Urol 22: 242-252, 2015.

15. Yoshino H, Seki N, Itesako T, Chiyomaru T, Nakagawa M and Enokida H: Aberrant expression of microRNAs in bladder cancer. Nat Rev Urol 10: 396-404, 2013.

16. Kikkawa N, Hanazawa T, Fujimura L, Nohata N, Suzuki H, Chazono H, Sakurai D, Horiguchi S, Okamoto Y and Seki N: miR-489 is a tumour-suppressive miRNA target PTPN11 in hypopharyngeal squamous cell carcinoma (HSCC). Br J Cancer 103: 877-884, 2010.

17. Fuse M, Kojima S, Enokida H, Chiyomaru T, Yoshino H, Nohata N, Kinoshita T, Sakamoto S, Naya Y, Nakagawa M, et al: Tumor suppressive microRNAs (miR-222 and miR-31) regulate molecular pathways based on microRNA expression signature in prostate cancer. J Hum Genet 57: 691-699, 2012. 
18. Shepherd FA, Crowley J, Van Houtte P, Postmus PE, Carney D, Chansky K, Shaikh Z and Goldstraw P; International Association for the Study of Lung Cancer International Staging Committee and Participating Institutions: The International Association for the Study of Lung Cancer lung cancer staging project: Proposals regarding the clinical staging of small cell lung cancer in the forthcoming (seventh) edition of the tumor, node, metastasis classification for lung cancer. J Thorac Oncol 2: 1067-1077, 2007.

19. Weaver VM, Petersen OW, Wang F, Larabell CA, Briand P, Damsky $\mathrm{C}$ and Bissell MJ: Reversion of the malignant phenotype of human breast cells in three-dimensional culture and in vivo by integrin blocking antibodies. J Cell Biol 137: 231-245, 1997.

20. Bissell MJ and Radisky D: Putting tumours in context. Nat Rey Cancer 1: 46-54, 2001.

21. Paszek MJ and Weaver VM: The tension mounts: Mechanics meets morphogenesis and malignancy. J Mammary Gland Biol Neoplasia 9: 325-342, 2004.

22. Paszek MJ, Zahir N, Johnson KR, Lakins JN, Rozenberg GI, Gefen A, Reinhart-King CA, Margulies SS, Dembo M, Boettiger $\mathrm{D}$, et al: Tensional homeostasis and the malignant phenotype. Cancer Cell 8: 241-254, 2005.

23. Kinoshita T, Hanazawa T, Nohata N, Kikkawa N, Enokida $H$ Yoshino H, Yamasaki T, Hidaka H, Nakagawa M, Okamoto Y, et al: Tumor suppressive microRNA-218 inhibits cancer cell migration and invasion through targeting laminin-332 in head and neck squamous cell carcinoma. Oncotarget 3: 1386-1400, 2012.

24. Kinoshita T, Nohata N, Hanazawa T, Kikkawa N, Yamamoto N, Yoshino H, Itesako T, Enokida H, Nakagawa M, Okamoto Y, et al: Tumour-suppressive microRNA-29s inhibit cancer cell migration and invasion by targeting laminin-integrin signalling in head and neck squamous cell carcinoma. Br J Cancer 109: 2636-2645, 2013.

25. Nishikawa R, Goto Y, Kojima S, Enokida H, Chiyomaru T, Kinoshita T, Sakamoto S, Fuse M, Nakagawa M, Naya Y, et al Tumor-suppressive microRNA-29s inhibit cancer cell migration and invasion via targeting LAMC1 in prostate cancer. Int J Oncol 45: 401-410, 2014

26. Wang Y, Zhang X, Li H, Yu J and Ren X: The role of miRNA-29 family in cancer. Eur J Cell Biol 92: 123-128, 2013.

27. Nishikawa R, Chiyomaru T, Enokida H, Inoguchi S, Ishihara T, Matsushita R, Goto Y, Fukumoto I, Nakagawa M and Seki N: Tumour-suppressive microRNA-29s directly regulate LOXL2 expression and inhibit cancer cell migration and invasion in renal cell carcinoma. FEBS Lett 589: 2136-2145, 2015

28. Yamamoto N, Kinoshita T, Nohata N, Yoshino H, Itesako T, Fujimura L, Mitsuhashi A, Usui H, Enokida H, Nakagawa M et al: Tumor-suppressive microRNA-29a inhibits cancer cell migration and invasion via targeting HSP47 in cervical squamous cell carcinoma. Int J Oncol 43: 1855-1863, 2013.

29. Mott JL, Kurita S, Cazanave SC, Bronk SF, Werneburg NW and Fernandez-Zapico ME: Transcriptional suppression of $\mathrm{mir}-29 \mathrm{~b}-1 / \mathrm{mir}-29 \mathrm{a}$ promoter by c-Myc, hedgehog, and NF-kappaB. J Cell Biochem 110: 1155-1164, 2010.

30. Wu DW, Hsu NY, Wang YC, Lee MC, Cheng YW, Chen CY and Lee H: c-Myc suppresses microRNA-29b to promote tumor aggressiveness and poor outcomes in non-small cell lung cancer by targeting FHIT. Oncogene 34: 2072-2082, 2015.

31. Chou J, Lin JH, Brenot A, Kim JW, Provot S and Werb Z: GATA3 suppresses metastasis and modulates the tumour microenvironment by regulating microRNA-29b expression. Nat Cell Biol 15: 201-213, 2013.

32. Maurer B, Stanczyk J, Jüngel A, Akhmetshina A, Trenkmann M, Brock M, Kowal-Bielecka O, Gay RE, Michel BA, Distler JH, et al: MicroRNA-29, a key regulator of collagen expression in systemic sclerosis. Arthritis Rheum 62: 1733-1743, 2010.

33. Roderburg C, Urban GW, Bettermann K, Vucur M, Zimmermann H, Schmidt S, Janssen J, Koppe C, Knolle P, Castoldi M, et al: Micro-RNA profiling reveals a role for miR-29 in human and murine liver fibrosis. Hepatology 53: 209-218, 2011

34. Matsuo M, Nakada C, Tsukamoto Y, Noguchi T, Uchida T, Hijiya N, Matsuura K and Moriyama M: MiR-29c is downregulated in gastric carcinomas and regulates cell proliferation by targeting RCC 2 . Mol Cancer 12: 15, 2013.

35. Barker HE, Cox TR and Erler JT: The rationale for targeting the LOX family in cancer. Nat Rev Cancer 12: 540-552, 2012.

36. Kagan HM and Li W: Lysyl oxidase: Properties, specificity, and biological roles inside and outside of the cell. J Cell Biochem 88 660-672, 2003
37. Vadasz Z, Kessler O, Akiri G, Gengrinovitch S, Kagan HM, Baruch Y, Izhak OB and Neufeld G: Abnormal deposition of collagen around hepatocytes in Wilson's disease is associated with hepatocyte specific expression of lysyl oxidase and lysyl oxidase like protein-2. J Hepatol 43: 499-507, 2005.

38. Kim YM, Kim EC and Kim Y: The human lysyl oxidase-like 2 protein functions as an amine oxidase toward collagen and elastin. Mol Biol Rep 38: 145-149, 2011

39. Erler JT and Weaver VM: Three-dimensional context regulation of metastasis. Clin Exp Metastasis 26: 35-49, 2009.

40. Kauppila S, Stenbäck F, Risteli J, Jukkola A and Risteli L: Aberrant type I and type III collagen gene expression in human breast cancer in vivo. J Pathol 186: 262-268, 1998.

41. Mackie EJ, Chiquet-Ehrismann R, Pearson CA, Inaguma Y, Taya K, Kawarada Y and Sakakura T: Tenascin is a stromal marker for epithelial malignancy in the mammary gland. Proc Natl Acad Sci USA 84: 4621-4625, 1987.

42. Zhu GG, Risteli L, Mäkinen M, Risteli J, Kauppila A and Stenbäck F: Immunohistochemical study of type I collagen and type I pN-collagen in benign and malignant ovarian neoplasms. Cancer 75: 1010-1017, 1995.

43. Kasashima H, Yashiro M, Kinoshita H, Fukuoka T, Morisaki T, Masuda G, Sakurai K, Kubo N, Ohira M and Hirakawa K: Lysyl oxidase-like 2 (LOXL2) from stromal fibroblasts stimulates the progression of gastric cancer. Cancer Lett 354: 438-446, 2014.

44. Ahn SG, Dong SM, Oshima A, Kim WH, Lee HM, Lee SA, Kwon SH, Lee JH, Lee JM, Jeong J, et al: LOXL2 expression is associated with invasiveness and negatively influences survival in breast cancer patients. Breast Cancer Res Treat 141: 89-99, 2013.

45. Peinado H, Moreno-Bueno G, Hardisson D, Pérez-Gómez E, Santos V, Mendiola M, de Diego JI, Nistal M, Quintanilla M, Portillo F, et al: Lysyl oxidase-like 2 as a new poor prognosis marker of squamous cell carcinomas. Cancer Res 68: 4541-4550, 2008.

46. Lamouille S, Xu J and Derynck R: Molecular mechanisms of epithelial-mesenchymal transition. Nat Rev Mol Cell Biol 15: 178-196, 2014.

47. Schietke R, Warnecke C, Wacker I, Schödel J, Mole DR, Campean V, Amann K, Goppelt-Struebe M, Behrens J, Eckardt KU, et al: The lysyl oxidases LOX and LOXL2 are necessary and sufficient to repress E-cadherin in hypoxia: Insights into cellular transformation processes mediated by HIF-1. J Biol Chem 285: 6658-6669, 2010.

48. Moon HJ, Finney J, Xu L, Moore D, Welch DR and Mure M: MCF-7 cells expressing nuclear associated lysyl oxidase-like 2 (LOXL2) exhibit an epithelial-to-mesenchymal transition (EMT) phenotype and are highly invasive in vitro. J Biol Chem 288: 30000-30008, 2013.

49. Peng L, Ran YL, Hu H, Yu L, Liu Q, Zhou Z, Sun YM, Sun LC, Pan J, Sun LX, et al: Secreted LOXL2 is a novel therapeutic target that promotes gastric cancer metastasis via the Src/FAK pathway. Carcinogenesis 30: 1660-1669, 2009.

50. Barry-Hamilton V, Spangler R, Marshall D, McCauley S, Rodriguez HM, Oyasu M, Mikels A, Vaysberg M, Ghermazien H, Wai C, et al: Allosteric inhibition of lysyl oxidase-like-2 impedes the development of a pathologic microenvironment. Nat Med 16: 1009-1017, 2010.

51. Voloshenyuk TG, Landesman ES, Khoutorova E, Hart AD and Gardner JD: Induction of cardiac fibroblast lysyl oxidase by TGF- $\beta 1$ requires PI3K/Akt, Smad3, and MAPK signaling. Cytokine 55: 90-97, 2011.

52. Roy R, Polgar P, Wang Y, Goldstein RH, Taylor L and Kagan HM Regulation of lysyl oxidase and cyclooxygenase expression in human lung fibroblasts: Interactions among TGF-beta, IL-1 beta, and prostaglandin E. J Cell Biochem 62: 411-417, 1996.

53. Tan J, Tong BD, Wu YJ and Xiong W: MicroRNA-29 mediates TGF $\beta 1$-induced extracellular matrix synthesis by targeting wnt/ $\beta$-catenin pathway in human orbital fibroblasts. Int J Clin Exp Pathol 7: 7571-7577, 2014.

54. Yang T, Liang Y, Lin Q, Liu J, Luo F, Li X, Zhou H, Zhuang S and Zhang H: miR-29 mediates TGFß1-induced extracellular matrix synthesis through activation of PI3K-AKT pathway in human lung fibroblasts. J Cell Biochem 114: 1336-1342, 2013. 